\title{
Long-term Clinical Follow-up of Patients with Familial Hypomagnesemia with Secondary Hypocalcemia
}

\author{
(1D) Elvan Bayramoğlu, (1) Melikşah Keskin, (1) Zehra Aycan, (1) Şenay Savaş-Erdeve, (D) Semra Çetinkaya \\ University of Health Sciences Turkey, Ankara Dr. Sami Ulus Obstetrics and Gynecology and Child Health and Diseases Training and Research \\ Hospital, Clinic of Pediatric Endocrinology, Ankara, Turkey
}

\begin{abstract}
What is already known on this topic?
Hypomagnesemia with secondary hypocalcemia (HSH) is a rare autosomal recessive disease which is characterized by selective magnesium malabsorption related to a mutation on the transient receptor potential melastatin 6 (TRPM6) gene. Affected cases are usually diagnosed when seizures occur, due to severe hypocalcemia and hypomagnesemia, during infancy. Early diagnosis and treatment play a crucial role in the prevention of sudden deaths, which although rare, occur due to irreversible neurological deficits and arrhythmias.
\end{abstract}

\section{What this study adds?}

Long-term follow-up data and treatment responses in six cases of HSH is presented. Of the four mutations identified in the TRPM6 gene, three were novel. Controversial topics in HSH are discussed, including short stature and testicular hypofunction. In addition, the genetic and clinical features of all Turkish patients previously reported are reviewed.

\begin{abstract}
Objective: Familial hypomagnesemia with secondary hypocalcemia (HSH) is an autosomal recessive disease caused by a mutation in the transient receptor potential melastatin 6 (TRPM6) gene and is characterized by selective magnesium malabsorption. Affected cases are usually diagnosed during infancy and usually present with seizures due to hypocalcemia and hypomagnesemia. Irreversible neurological deficits and arrhythmias can be observed without appropriate treatment. The aim was to evaluate the long-term follow-up of patients with genetically confirmed HSH.

Methods: A total of six patients with HSH, two of whom were siblings, were included. Age at diagnosis, clinical, laboratory and follow-up data on admission were recorded. All 39 exons of the TRPM6 gene and flanking exon-intron junctions from genomic DNA were amplified and sequenced in all cases.

Results: The median (range) follow-up duration was 12.1 (7.6-21.7) years. All cases were diagnosed in infancy. Four different mutations, three of which had not been previously reported, were detected in the TRPM6 gene. Treatment compliance was good and there were no severe complications in the long-term follow-up of cases. However, mental retardation, specific learning difficulty and attention deficit/ hyperactive disorder were observed as comorbidities.

Conclusion: Of the four different TRPM6 mutations in this small cohort, three had not been previously reported. The long-term prognosis of HSH appears to be good, given early diagnosis and good treatment compliance. This long-term follow-up and prognostic data and the three novel mutations will contribute to the published evidence concerning this rare condition, HSH, and it is hoped will prevent negative outcomes.
\end{abstract}

Keywords: Hypomagnesemia, hypocalsemia, TRPM6 mutation

Address for Correspondence: Elvan Bayramoğlu MD, University of Health Sciences Turkey, Ankara Dr. Sam Ulus Obstetrics and Gynecology and Child Health and Diseases Training and Research Hospital, Clinic of Pediatric Endocrinology, Ankara, Turkey

Phone: +90 3123056513 E-mail: elvanbayramoglu@gmail.com ORCID: orcid.org/0000-0002-6732-8823
Conflict of interest: None declared Received: 14.08 .2020 Accepted: 03.02.2021 


\section{Introduction}

Familial hypomagnesemia with secondary hypocalcemia (HSH) is a rare, autosomal recessively inherited disease, due to transient receptor potential melastatin 6 (TRPM6) gene mutation. HSH is seen in the early infancy period and may be characterized by hypocalcemia secondary to hypomagnesemia and symptoms of neuromuscular excitability, such as generalized seizures, muscle cramps and agitation (1). TRPM6 functions as a cation channel with high permeability to magnesium (Mg) ions $\left(\mathrm{Mg}^{+2}\right)$ and the activity of the TRPM6 protein is regulated by intracellular $\mathrm{Mg}^{+2}$ levels (2). It is expressed in intestine and renal distal convoluted tubules. TRPM6 mutations cause hypomagnesemia by intestinal and renal Mg wasting. Hypocalcemia in $\mathrm{HSH}$ is secondary to parathyroid hormone (PTH) resistance and decreased PTH release because of hypomagnesemia $(3,4)$. Mg plays essential roles in normal cell physiology throughout the body. It is difficult to distinguish the clinical manifestations of HSH from other causes of hypocalcemia such as hypoparathyroidism. If hypomagnesemia cannot be detected and treated rapidly, fatal convulsions, irreversible neurodevelopmental deficits and life-threating arrhythmias may develop. No genotype-phenotype correlation between mutations in TRPM6 and the severity of HSH have been identified.

In this study, clinical features and long-term follow-up data of six patients with HSH who had TRPM6 mutation are presented.

\section{Methods}

\section{Patients}

The clinical files of six HSH patients from five different families and who were followed-up in our clinic since 1998 were evaluated retrospectively. Primary hypomagnesemia was diagnosed biochemically and the low serum $\mathrm{Mg}^{+2}$ levels present a requirement for high dose $\mathrm{Mg}^{+2}$ treatment. Exclusion criteria were secondary hypomagnesemia, such as being an infant of diabetic mother, intestinal malabsorption, and clinical conditions such as short bowel syndrome and exposure to various drugs, such as proton pump inhibitors, antibiotics, diuretics, and chemo-therapeutic agents. The levels of serum electrolytes, serum creatinine $(\mathrm{Cr})$, alkaline phosphatase, PTH, $25(\mathrm{OH})$ vitamin D and urinary $\mathrm{Mg}^{+2}$, calcium $(\mathrm{Ca})$, phosphate $(\mathrm{P})$ and $\mathrm{Cr}$ were evaluated in all cases.

The ultra-filtrated fraction of serum $\mathrm{Mg}^{+2}$ was calculated as UFMg $=0.7 x$ SMg. Renal $\mathrm{Mg}^{+2}$ handling was assessed by calculating fractional $\mathrm{Mg}^{+2}$ excretion (normal range 3 to $5 \%$ for normomagnesemic individuals) with FeMg = (UMgxSCr $)$ / (UFMgxUCr) $\times 100$ where $\mathrm{Fe}$ is fractional excretion, SMg is serum $\mathrm{Mg}^{+2}$, UMg is urinary $\mathrm{Mg}^{+2}, \mathrm{SCr}$ is serum $\mathrm{Cr}$ and $\mathrm{UCr}$ is urine creatinine. Hypercalciuria was defined as urine $\mathrm{Ca} / \mathrm{Cr}$ ratio ( $\mathrm{UCa} / \mathrm{UCr}$ ) higher than $0.21 \mathrm{mg} / \mathrm{mg}$. Renal ultrasound was performed to rule out nephrocalcinosis. Clinical and laboratory findings of the patients undergoing $\mathrm{Mg}^{+2}$ treatment were evaluated regularly at outpatient clinic visits. Diarrhea is the main side effect of high oral Mg administration and was defined as three or more loose or watery bowel movements per day. Diagnoses of all cases were confirmed by genetic analysis. Neurodevelopmental status was assessed by Revised Wechsler Intelligence Scale for children, which was evaluated by the department of child and adolescent psychiatry.

The clinical and laboratory findings including serum $\mathrm{Ca}$, serum $\mathrm{Mg}^{+}$, alkaline phosphatase, PTH, $25(\mathrm{OH})$ vitamin $\mathrm{D}$ and urinary $\mathrm{Mg}^{+2}, \mathrm{Ca}, \mathrm{P}, \mathrm{Cr}$, of the parents were also evaluated.

All participants and their parents received oral and written information concerning the study before providing signed consent. All procedures performed in this study were in accordance with ethical standards. This study was approved by the Sultangazi Haseki Training and Research Hospital Local Ethical Committee (no: 2020-58, date: 14.05.2020).

\section{Mutational Analysis}

Extraction of DNA from leukocytes was performed using standard protocols. TRPM6 mutational screening was performed by Single-Strand Conformation Polymorphism analysis. For that purpose, an overlapping set of polymerase chain reaction primers, based on the sequence of the human TRPM6 gene (genomic contig GenBank accession number AL354795), was used to amplify the complete coding sequence and the intron/exon boundaries from genomic DNA (primer sequences available upon request). Amplified products were separated on polyacrylamide gels by electrophoresis (Multiphor II; Pharmacia Biotech ${ }^{\star}$, Sweden). Subsequently, exons with conformational variants were directly sequenced from both strands using an Applied Biosystems 310 Genetic Analyzer (Applied Biosystems, USA).

\section{Results}

Five male cases and one female case from five different families, diagnosed with primary hypomagnesemia, were included in the study. All patients presented with afebrile convulsions from between one and nine months of age at first admission. Consanguineous marriage was present in three families, one of which contained two affected siblings. 
The clinical and laboratory findings of the subjects at the time of diagnosis and follow-up are presented in Table 1. The follow-up period of the subjects ranged from 7.5 to 21.6 years.

All cases were diagnosed with hypomagnesemia on admission, except one case (F4). This patient was admitted with a seizure at 3.5 months of age and the initial diagnosis was hypoparathyroidism because serum Mg was not assesed. Anticonvulsant treatment (phenytoin, phenobarbital) was started due to persistence of seizures despite calcitriol treatment. Hypomagnesemia was eventually diagnosed at seven months of age with the

\begin{tabular}{|c|c|c|c|c|c|c|}
\hline & F1.1 & F1.2 & $\mathrm{F} 2$ & F3 & $\mathrm{F} 4$ & F5 \\
\hline Age on admission (months) & 9 & 1 & 1.5 & 3 & 3.5 & 5 \\
\hline Age on diagnosis (months) & 9 & 1 & 1.5 & 3 & 7 & 5 \\
\hline Gender & Male & Male & Male & Female & Male & Male \\
\hline Symptoms on admission & Seizures & Seizures & Seizures & Seizures & Seizures & Seizures \\
\hline $\begin{array}{l}\text { Serum Ca on admission } \\
(2.1-2.55 \mathrm{mmol} / \mathrm{L})\end{array}$ & 1.68 & 1.82 & 1.92 & 1.62 & 1.42 & 1.55 \\
\hline $\begin{array}{l}\text { PTH on admission }(\mathrm{pg} / \mathrm{mL}) \\
(\mathrm{n}=9-67)\end{array}$ & 4.9 & 3.8 & 5.5 & 6.5 & 9.1 & 8.7 \\
\hline $\begin{array}{l}\text { Serum Mg on admission } \\
(0.66-1.07 \mathrm{mmol} / \mathrm{L})\end{array}$ & 0.23 & 0.16 & 0.21 & 0.18 & 0.13 & 0.17 \\
\hline $\begin{array}{l}\text { Age at last control } \\
\text { (years) }\end{array}$ & 22 & 15.3 & 8.4 & 7.8 & 9.4 & 22 \\
\hline Height SDS at last control & -0.93 & -0.92 & 0.8 & 2.32 & -0.22 & -0.43 \\
\hline Follow-up period (years) & 21.2 & 15.2 & 8.3 & 7.6 & 8.9 & 21.7 \\
\hline $\begin{array}{l}\text { Magnesium doses at last } \\
\text { control (mg/kg/day) }\end{array}$ & 12.5 & 13.6 & 13.5 & 31.5 & 24 & 13 \\
\hline Neurodevelopmental status & $\begin{array}{l}\text { Mild-moderate } \\
\text { MR }\end{array}$ & SLD & Normal & Normal & Normal & ADHD \\
\hline $\begin{array}{l}\text { Serum Mg at final control } \\
(0.66-1.07 \mathrm{mmol} / \mathrm{L})\end{array}$ & 0.62 & 0.59 & 0.51 & 0.71 & 0.72 & 0.59 \\
\hline $\begin{array}{l}\text { Serum } \mathrm{Ca} \text { at final control } \\
(2.1-2.55 \mathrm{mmol} / \mathrm{L})\end{array}$ & 2.25 & 2.52 & 2.37 & 2.52 & 2.42 & 2.52 \\
\hline $\operatorname{FeMg}(\%)(n=3-5 \%)$ & 2.1 & 1.9 & 1.2 & 5.1 & 5.9 & 1.8 \\
\hline Urinary $\mathrm{Ca} / \mathrm{Cr}$ & 0.1 & 0.06 & 0.19 & 0.04 & 0.06 & 0.036 \\
\hline Nefrocalsinosis & No & No & No & No & No & No \\
\hline Parental consanguinity & Yes & Yes & Yes & Yes & No & No \\
\hline Affected gene & TRPM6 & TRPM6 & TRPM6 & TRPM6 & TRPM6 & TRPM6 \\
\hline Mutation & $\begin{array}{l}\text { c. } 3158 \text { A > G } \\
(\text { p.Tyr } 1053 \text { Cy) }\end{array}$ & $\begin{array}{l}\text { c.3158A > G } \\
\text { (p.Tyr1053Cys) }\end{array}$ & $\begin{array}{l}{ }^{*} \mathrm{C} .841(+1) \\
\mathrm{G}>\mathrm{A}\end{array}$ & $\begin{array}{l}{ }^{*} \text { c. } 1751 \text { A > G } \\
\text { (p.His584Arg) }\end{array}$ & $\begin{array}{l}{ }^{*} \mathrm{C} .841(+1) \\
\mathrm{G}>\mathrm{A}\end{array}$ & $\begin{array}{l}{ }^{*} \mathrm{c} .3514 \mathrm{C}>\mathrm{T} \\
(\mathrm{p} . \operatorname{Arg} 1172 *)\end{array}$ \\
\hline Localization & Exon 23 & Exon 23 & $\begin{array}{l}\text { IVS7 } \\
\text { donorsplice site }\end{array}$ & Exon 16 & $\begin{array}{l}\text { IVS7 } \\
\text { donorsplice } \\
\text { site }\end{array}$ & Exon 25 \\
\hline Mutation/mother & $\begin{array}{l}\text { c. } 3158 \text { A > G } \\
\text { (p.Tyr 1053Cy) } \\
\text { (het) }\end{array}$ & $\begin{array}{l}\text { c. } 3158 \text { A > G } \\
\text { (p.Tyr 1053Cy) } \\
\text { (het) }\end{array}$ & $\begin{array}{l}{ }^{*} \mathrm{C} .841(+1) \\
\mathrm{G}>\mathrm{A} \text { (het) }\end{array}$ & $\begin{array}{l}{ }^{*} \mathrm{c} .1751 \mathrm{~A}>\mathrm{G} \\
\text { (p.His584Arg) } \\
\text { (het) }\end{array}$ & $\begin{array}{l}{ }^{*} \mathrm{C} .841(+1) \\
\mathrm{G}>\mathrm{A} \text { (het) }\end{array}$ & $\begin{array}{l}{ }^{*} \mathrm{C} .3514 \mathrm{C}>\mathrm{T} \\
\left(\mathrm{p} . \operatorname{Arg} 1172^{*}\right) \\
\text { (het) }\end{array}$ \\
\hline Mutation/father & $\begin{array}{l}\text { c. } 3158 \text { A > G } \\
\text { (p.Tyr1053Cy) } \\
\text { (het) }\end{array}$ & $\begin{array}{l}\text { c. } 3158 \text { A > G } \\
\text { (p.Tyr1053Cy) } \\
\text { (het) }\end{array}$ & $\begin{array}{l}{ }^{*} \mathrm{C} .841(+1) \\
\mathrm{G}>\mathrm{A} \text { (het) }\end{array}$ & $\begin{array}{l}{ }^{*} \mathrm{c} .1751 \mathrm{~A}>\mathrm{G} \\
\text { (p.His584Arg) } \\
\text { (het) }\end{array}$ & $\begin{array}{l}{ }^{*} \mathrm{C} .841(+1) \\
\mathrm{G}>\mathrm{A} \text { (het) }\end{array}$ & $\begin{array}{l}{ }^{*} \mathrm{C} .3514 \mathrm{C}>\mathrm{T} \\
\text { (p.Arg } 1172 *) \\
\text { (het) }\end{array}$ \\
\hline
\end{tabular}


observation of hypomagnesemia and recurrent resistant seizures despite calcitriol and anticonvulsant therapy.

On admission the range of serum $\mathrm{Mg}^{+2}$ levels was 0.13-0.23 $\mathrm{mmol} / \mathrm{L}$, serum Ca levels were 1.42-1.92 mmol/L, and PTH levels were 3.8-9.1 pg/mL. Following $\mathrm{Mg}^{+2}$ treatment, serum $\mathrm{Ca}$ and PTH levels returned to normal levels during followup of all patients.

Oral $\mathrm{Mg}^{+2}$ treatment doses were adjusted to sustain normocalcemia, according to the tolerance of the cases. Dose was not increased in patients with diarrhea. Treatment doses ranged between 12.5 and $31.5 \mathrm{mg} / \mathrm{kg} /$ day. In two cases (F3, F4), serum $\mathrm{Mg}^{+2}$ concentrations were maintained at the reference intervals with oral treatment and were subnormal in four cases (0.51-0.59 mmol/l). However, no symptoms were observed. Fractional $\mathrm{Mg}^{+2}$ excretion was between $1.2 \%$ and $5.9 \%$. Hypercalciuria and nephrocalcinosis were not detected in any case.

None of the patients had short stature at the last follow-up. Height standard deviation (SD) scores ranged from -0.93 to $2.36 \mathrm{SD}$. In one case, who was diagnosed at nine months of age (F1.1), mild-to-moderate mental retardation was observed while his brother had a specific learning difficulty (F1.2). In another case (F5) attention deficit and attention deficit/hyperactivity disorder (ADHD) was diagnosed. Neurodevelopmental status of all patients, except F1.1 and F1.2, were consistent with their ages.
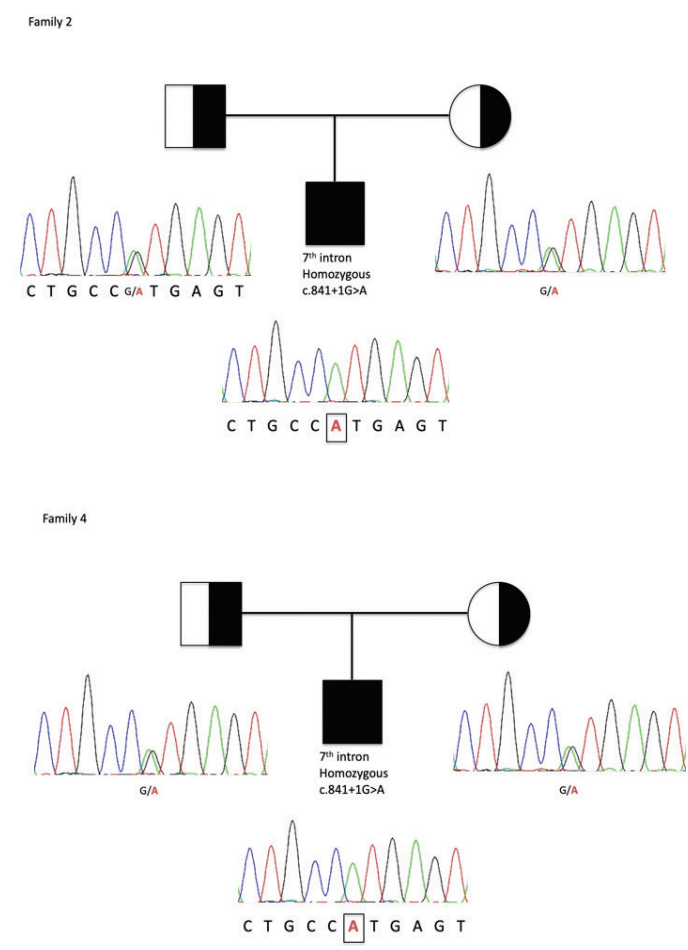

\section{Mutation Analysis}

Four different mutations were detected in the TRPM6 gene in six cases out of five families (Table 1). A homozygous missense mutation, which has been identified previously in a Turkish family on Exon 23 was detected in F1.1 and F1.2. [C.3158A > G, (p.Tyr1053Cys)]. Both of the parents were heterozygous carriers of this mutation. Two patients from non-consanguineous families (F2 and F4) had the same splice-site mutation, which had not been previously described (IVS7 splice-site, c.841 $(+1) \mathrm{G}>\mathrm{A}$ ). This mutation affected an essential splice site. The parents of these patients were heterozygous for the same mutation. A missense mutation [c.1751A > G, (p.His584Arg)] on Exon 16 was detected in patient F3. This variant was reported in the ExAC database (exac.broadinstitute.org) as a rare variant at a frequency of 29/120000 and classified as a variant of unknown significance. However, this variant was predicted to be disease causing by in silico analysis in Mutation Taster. Furthermore, the parents of these patients were heterozygous for the same variant. In F5, a nonsense mutation on exon 25 [c.3514C > T, (p.Arg1172)], previously reported in the ExAC database as a rare variant with a frequency of $1 / 120000$, was detected. This mutation is predicted to cause a premature stop codon to be formed; the parents were heterozygous for this mutation. Therefore, this mutation, which was not previously reported in any patient, was accepted as a pathogenic variant (Figure 1).

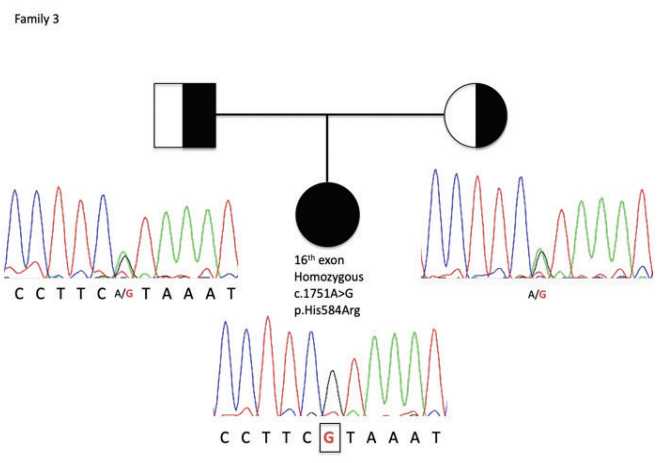

familys

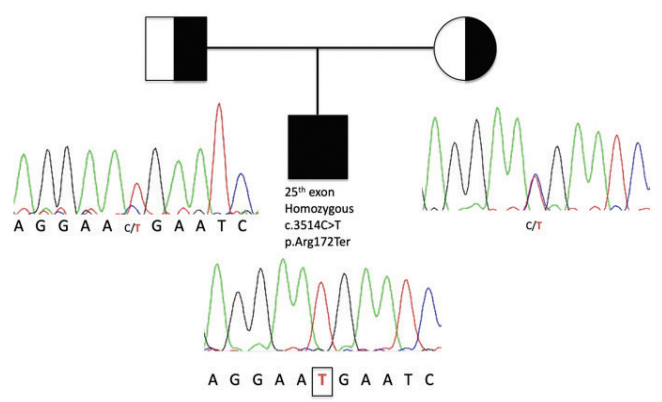

Figure 1. Pedigree and mutational analysis of the patients with novel TRPM6 variant 
The clinical and laboratory findings, including serum $\mathrm{Ca}$, serum $\mathrm{Mg}^{+}$, alkaline phosphatase, PTH, $25(\mathrm{OH})$ vitamin D and urinary $\mathrm{Mg}^{+2}, \mathrm{Ca}, \mathrm{P}$, and $\mathrm{Cr}$, of the heterozygous parents were evaluated and were found to be unremarkable.

\section{Discussion}

In this study, the long-term follow-up results of six genetically confirmed $\mathrm{HSH}$ patients are presented. Three novel mutations in the TRPM6 gene were identified, in addition to one known pathogenic mutation. The first presentation of all cases was afebrile seizures in the first year of life. Mild mental retardation, specific learning difficulty and ADHD were found as comorbidities. On long-term followup, growth was normal with Mg supplementation and maintenance of normal serum Ca levels.

$\mathrm{Mg}^{+2}$ is a cofactor for many enzymes and transporters, including phosphatases and phosphokinases. It is required for energy storage and use, and plays an important role in the synthesis of nucleic acids and proteins (5). Therefore, insufficient cellular $\mathrm{Mg}^{+2}$ concentrations affect many systems. Mg is strictly regulated by intestinal absorption and renal excretion and/or reabsorption. Intestinal absorption of $\mathrm{Mg}^{+2}$ occurs in the jejunum and the ileum. Most of the renalfiltered $\mathrm{Mg}^{+2}$ is absorbed by passive paracellular transport from the proximal tubule and the thick ascending loop of Henle. In the distal convoluted tubule, the fine tuning of $\mathrm{Mg}^{+2}$ equilibrium is made by active transcellular transport (6).

Hypomagnesemia in children may develop secondary to clinical conditions, such as intestinal malabsorption, short bowel syndrome, being the infant of a diabetic mother and the use of various drugs (proton pump inhibitors, antibiotics, diuretics, chemotherapeutic agents) and may also develop as a result of primary familial hypomagnesemia disorders (7). HSH is usually characterized by clinical findings, such as restlessness, tremor, muscle cramps, tetany, perioral cyanosis and generalized convulsions, in neonates or in the early infancy period. Mg levels are normal at delivery due to free passage of $\mathrm{Mg}^{+2}$ across the placenta. Mg levels progressively decrease within weeks or months and clinical findings begin (8). The age at presentation varies between two weeks and nine months, and in $96 \%$ of patients, generalized seizures have been reported as a presenting symptom, which was the finding in all of our cases $(9,10)$.

Hypocalcemia and hypoparathyroidism may cause misdiagnosis of primary hypomagnesemia if the serum Mg level was not assessed (11), as in our F4 case. Improper or delayed diagnosis and treatment may cause recurrent, convulsions and irreversible neurological damage (9). The mechanism by which hypomagnesemia causes neurological damage is not known; a defect of voltage-dependent Mg passage in the $\mathrm{N}$-methyl-D aspartate receptor is thought to trigger convulsions (12). Abnormal development and neural tube defects have been reported in TRPM6 knock-out mice. In addition, mental retardation, paranoid delusions and death due to recurrent and eventually fatal seizures were reported in cases with delayed diagnosis $(8,9,13)$. Mental retardation was diagnosed in one of our cases (F1.1), who was diagnosed relatively late, at 9 months of age. In contrast, his brother had specific learning difficulty even though (F1.2) he had an early diagnosis at 1 month of age and was treated apropriately. Interestingly, Lainez et al (14) also described a case with mental retardation and the same genetic mutation decribed in the siblings in our series. Lastly, in one patient who was diagnosed at 5 months of age, we observed ADHD (F5), and another patient with recurrent seizures had normal neurological development (F4).

Short stature has been reported rarely in HSH patients and the underlying mechanism is not completely explained $(9,12,15)$. Short stature may be the result of late diagnosis and/or non-compliance with treatment, but it is also seen in cases diagnosed in early infancy and treated appropriately. So, it has been suggested that short stature may be a clinical feature of the disease (15). There was no short stature in any of our patients.

TRPM6 has been shown to be expressed in testicles, but the effect of mutations on male fertility is unknown (16). In two 21-years-old male patients, puberty was consistent with Tanner stage 5 and the sperm number, motility and morphology were normal in the spermiogram. In our 15-years-old male, puberty was consistent with stage 5, but a spermiogram could not be performed. None of the patients had any children.

The standard treatment in $\mathrm{HSH}$ is high dose $\mathrm{Mg}^{+2}$. On diagnosis, intravenous or intramuscular administration can be preferred and maintenance therapy is high dose oral $\mathrm{Mg}^{+2}$. A significant variation of mean oral Mg dose (0.41-3.9 $\mathrm{mmol} / \mathrm{kg}$ ) has been reported between patients and centers $(9,17)$. In the literature, it has been shown that serum Mg levels do not reach normal values in patients with $\mathrm{HSH}$, with the exception of only three cases undergoing high dose Mg treatment $(9,14)$. In line with the litherature, in our study, oral $\mathrm{Mg}$ doses ranged between 0.51-1.28 mmol/kg (12.5$31.5 \mathrm{mg} / \mathrm{kg}$ ). Normal serum Mg levels near the lower limit of the reference intervals were obtained in only two patients under Mg treatment.

Physiological fractional renal Mg excretion is 3-5\%, but this falls below $0.5-1 \%$ in order to maintain serum Mg levels 
in the presence of hypomagnesemia $(18,19)$. In the current study fractional renal Mg excretion was measured over $5 \%$ in two patients whose serum Mg levels were normal but close to the lower limit of the reference intervals. In patients with subnormal course of serum Mg levels, renal Mg excretion was over $1 \%(1.2-2.1 \%)$. Increased renal Mg excretion has a clear role in the pathogenesis of the disease and prevents the achievement of physiological serum Mg values, despite adequate treatment. In other words, the treatment should not provide normomagnesemia, but should provide normocalcemia, and if serum $\mathrm{Ca}$ is normal, Mg doses should not be increased.

It has been shown that the mutations previously identified in patients with $\mathrm{HSH}$ are not localized in a specific region and may be distributed across many areas of the TRPM6 protein $(3,9,14)$. To date, 11 different mutations have been identified in 17 Turkish patients (Table 2) $(9,14,15,20,21,22)$. The most common TRPM6 mutations in Turkish patients were c.5775A $>$ G (in five cases from three nonconsanguineous families), c.469G $>\mathrm{T}$ (in three cases from three family with), and c.3158A $>$ G (in three cases from two non-consanguineous families). In our study, missense mutation (F1.1 and 1.2) was found in the twenty third exon, previously described in a Turkish case by Lainez et al (14). In addition, we demonstrated three novel mutations. The first mutation, c.841 $(+1) \mathrm{G}>\mathrm{A}$, was found in the IVS7 splice site and was present in two unrelated patients (F2 and F4). The second novel mutation was c.3514C > T (p.Arg1172) in the twenty fifth exon. It was reported as a rare variant in the database, however it causes the formation of a premature stop codon and both parents were heterozygous carriers for the same mutation; therefore this mutation is accepted as pathogenic. The missense variant found in F3 was c. 1751 A > G (p.His584Arg) and both parents were heterozygous carriers for the same mutation. This variant was reported in ClinVar database as a variant of unknown significance. It may be pathogenic when evaluated together

Table 2. Clinical data and results of the TRPM6 mutational analyses of Turkish patient with familial hypomagnesemia with secondary hypocalcemia

\begin{tabular}{|c|c|c|c|c|c|c|c|c|c|c|}
\hline $\begin{array}{l}\text { Turkish } \\
\text { patients } \\
\text { (references) }\end{array}$ & Gender & $\begin{array}{l}\text { Age at } \\
\text { diagnosis }\end{array}$ & $\begin{array}{l}\text { Symptoms at } \\
\text { manifestation }\end{array}$ & $\begin{array}{l}\text { Initial } \\
\text { serum } \\
\mathrm{Mg}^{+2} \\
(\mathrm{mmol})\end{array}$ & $\begin{array}{l}\text { Initial } \\
\text { serum } \\
\mathrm{Ca}^{+2} \\
(\mathrm{mmol})\end{array}$ & $\begin{array}{l}\text { Oral/ } \\
\mathrm{IMMg}^{+2} \\
(\mathrm{mmol} / \\
\mathrm{kg} / \mathrm{d})\end{array}$ & $\begin{array}{l}\mathrm{Mg}^{+2} \\
\text { under } \\
\text { therapy }\end{array}$ & $\begin{array}{l}\text { FeMg } \\
(\%)\end{array}$ & $\begin{array}{l}\text { Additional } \\
\text { finding }\end{array}$ & Mutation \\
\hline P1 (9) & F & $2 \mathrm{mo}$ & Seizures & 0.21 & 1.63 & $1.03(0)$ & 0.59 & 2.6 & - & c. $1769 \mathrm{G}>\mathrm{G}$ \\
\hline P2 (9) & M & $6 \mathrm{yr}$ & Seizures & ND & 1.29 & $0.62(0)$ & 0.57 & 2.8 & MR & c. $2667+\mathrm{G}>\mathrm{A}$ \\
\hline P3 $(9)^{\mathrm{a}}$ & M & $3 \mathrm{mo}$ & Seizures & 0.09 & 1.6 & $0.54(\mathrm{o})$ & 0.33 & ND & - & c. $5775 \mathrm{~A}>\mathrm{G}$ \\
\hline P4 (9) ${ }^{\mathrm{a}}$ & M & $4 \mathrm{mo}$ & Asymptomatic & 0.16 & 1.75 & $0.94(0)$ & 0.53 & ND & - & c. $5775 \mathrm{~A}>\mathrm{G}$ \\
\hline P5 (9) & M & $4 \mathrm{mo}$ & Seizures & 0.1 & 1.45 & $2.0(0)$ & 0.50 & 3.7 & - & c. $469 \mathrm{G}>\mathrm{T}$ \\
\hline P6 (9) & F & $3 \mathrm{wk}$ & Seizures & 0.2 & 1.72 & $0.93(0)$ & 0.52 & ND & - & c. $2667+G>A$ \\
\hline P7 (14) & F & Infancy & Seizures & 0.05 & 1.78 & 0.97 (o) & 0.50 & ND & MR & C. $3158 A>G$ \\
\hline P8 (14) & $\mathrm{F}$ & $8 \mathrm{mo}$ & Seizures & 0.2 & 1.6 & $0.5(0)$ & 0.53 & ND & - & $\begin{array}{l}\text { C. } 469 \mathrm{G}>\mathrm{T}+ \\
5261 \mathrm{G}>\mathrm{A}\end{array}$ \\
\hline P9 (21) & $\mathrm{F}$ & $2 \mathrm{mo}$ & Seizures & $<0.24$ & 1.5 & $1.6(0)$ & 0.57 & 3.9 & - & $\begin{array}{l}\text { c. } 3447 \text { delT }>\text { p. } \\
\text { F1149fs }\end{array}$ \\
\hline P10 $(15)^{b}$ & M & $3 \mathrm{mo}$ & Seizures & 0.16 & 1.8 & $\begin{array}{l}0.2(\mathrm{o}) / \\
0.8 \text { (im) }\end{array}$ & 0.38 & 0.1 & - & C. $3556 \mathrm{C}>\mathrm{T}$ \\
\hline P11 $(15)^{b}$ & F & $3 \mathrm{mo}$ & Seizures & 0.08 & 1.0 & $\begin{array}{l}0.4(\mathrm{o}) / \\
0.9(\mathrm{im})\end{array}$ & 0.45 & 0.1 & $\begin{array}{l}\text { Short } \\
\text { stature }\end{array}$ & C. $3556 \mathrm{C}>\mathrm{T}$ \\
\hline P12 (15) & M & $1 \mathrm{mo}$ & Seizures & 0.2 & 2.4 & 0.9 (im) & 0.41 & 0.8 & - & C. $5775 \mathrm{~A}>\mathrm{G}$ \\
\hline P13 (15) & M & $1 \mathrm{yr}$ & Seizures & 0.14 & 2.6 & $0.8(0)$ & 0.75 & 2.7 & - & c. $1444-1$ G > T \\
\hline $\mathrm{P} 14(15)^{\mathrm{c}}$ & M & $1 \mathrm{mo}$ & Seizures & 0.5 & 1.7 & $\begin{array}{l}0.6(0) / 3.7 \\
(\mathrm{im})\end{array}$ & 0.58 & 2.3 & $\begin{array}{l}\text { Short } \\
\text { stature }\end{array}$ & c. $5775 \mathrm{~A}>\mathrm{G}$ \\
\hline $\mathrm{P} 15(15)^{\mathrm{c}}$ & $\mathrm{F}$ & $3 \mathrm{mo}$ & Seizures & 0.5 & 1.7 & $\begin{array}{l}0.5(\mathrm{o}) / 7 \\
(\mathrm{im})\end{array}$ & 0.66 & 1.9 & - & c. $5775 \mathrm{~A}>\mathrm{G}$ \\
\hline P16 (22) & M & $1 \mathrm{mo}$ & Seizures & 0.16 & 1.42 & $0.7(0)$ & 0.69 & ND & - & $469 \mathrm{G}>\mathrm{T}+$ \\
\hline P17 (23) & M & $8 \mathrm{mo}$ & $\begin{array}{l}\text { Seizures } \\
+ \text { hypotonia }\end{array}$ & 0.19 & 1.67 & $1.72(0)$ & ND & 0.18 & - & $3178 \mathrm{~A}>\mathrm{T}$ \\
\hline
\end{tabular}

a, b, c: siblings, F: female, M: male, yr: year, mo: month, wk: week, o: oral, im: intramusculer, ND: not defined, MR: mental retardation, Mg: magnesium, FeMg: fractional magnesium excretions, Ca: calcium 
with the clinical features and segregation analysis of the patient, however functional analysis is required.

In a study, in which $28 \mathrm{HSH}$ cases were evaluated regarding genotype-phenotype relationship, normal serum Mg levels were obtained by Mg treatment in two cases with a deletion in exon 32 or 33 (9). Since mutations in these exons only affect a small portion of the TRPM6 protein, it has been suggested that the channel function may be partially protected. However, it was reported, after functional analysis, that all mutations resulted in complete loss of function in the TRPM6 ion channel and no genotypephenotype correlation was reported (9). In another study, the age of admission, serum Mg and Ca levels and oral Mg doses have been compared in 30 cases previously described in the literature. No relation was found between genotype and these clinical and laboratory parameters (10). In our study, clinical and laboratory findings of all patients with different mutations were similar. In addition, in one patient, normal serum Mg levels were obtained with Mg treatment, while Mg levels were subnormal in another patient with the same mutation, suggesting phenotypic variability despite genotypic homogeneity.

Mg treatment and close follow-up are essential to prevent clinical symptoms and to obtain normal Ca metabolism in $\mathrm{HSH}$ patients. In our case series, we observed that with an early diagnosis, appropriate treatment and good treatment compliance the long-term (about 15 years) prognosis was good and no serious complications developed in $\mathrm{HSH}$ patients, similar to the study of Astor et al (16) which reported long-term (about 40 years) follow-up data.

\section{Study Limitations}

The main limitation of our study was the small number of patients. Additionally, functional analysis could not be performed although we identified new pathogenic mutations.

\section{Conclusion}

Evaluation of our cases with HSH revealed a homogenous clinical picture at manifestation with onset in the first year of life with generalized seizures. However there were heterogenous molecular findings, including four different TRPM6 mutations, of which three were novel. Early diagnosis, appropriate treatment and good treatment compliance are crucial for the prognosis. Enlightment of the genetic etiology of autosomal recessive disorders like HSH is important, and can reveal mutations especially in populations where consanginous marriages are prevalent. Molecular studies in cases with HSH and their families will contribute to increase our knowledge about Mg homeostasis. Determination of the genetic mutation is also useful to know the prognosis and associated comorbidities.

\section{Acknowledgement}

We thank Professor Karl Peter Schlingmann, University Children's Hospital, Department of General Pediatrics in Münster/Germany and Naz Güleray, University of Health Sciences Turkey, Ankara Dr. Sami Ulus Obstetrics and Gynecology and Child Health and Diseases Training and Research Hospital, Department of Medical Genetic in Ankara, Turkey for genetic analyses and sequencing data.

\section{Ethics}

Ethics Committee Approval: This study was approved by the Sultangazi Haseki Training and Research Hospital Local Ethical Committee (no: 2020-58, date: 14.05.2020).

Informed Consent: All participants and their parents received oral and written information concerning the study before providing signed consent.

Peer-review: Externally peer-reviewed.

\section{Authorship Contributions}

Surgical and Medical Practices: Elvan Bayramoğlu, Melikşah Keskin, Zehra Aycan, Şenay Savaş-Erdeve, Semra Çetinkaya, Concept: Elvan Bayramoğlu, Semra Çetinkaya, Design: Elvan Bayramoğlu, Semra Çetinkaya, Data Collection or Processing: Elvan Bayramoğlu, Melikşah Keskin, Zehra Aycan, Şenay Savaş-Erdeve ve Semra Çetinkaya, Analysis or Interpretation: Elvan Bayramoğlu, Zehra Aycan, Semra Çetinkaya, Literature Search: Elvan Bayramoğlu, Melikşah Keskin, Zehra Aycan, Şenay Savaş-Erdeve ve Semra Çetinkaya, Writing: Elvan Bayramoğlu, Semra Çetinkaya.

Financial Disclosure: The authors declared that this study received no financial support.

\section{References}

1. Schlingmann KP, Weber S, Peters M, Niemann Nejsum L, Vitzthum H, Klingel K, Kratz M, Haddad E, Ristoff E, Dinour D, Syrrou M, Nielsen S, Sassen M, Waldegger S, Seyberth HW, Konrad M. Hypomagnesemia with secondary hypocalcemia is caused by mutations in TRPM6, a new member of the TRPM gene family. Nat Genet 2002;31:166-170. Epub 2002 May 28

2. Topala CN, Groenestege WT, Thébault S, van den Berg D, Nilius B, Hoenderop JG, Bindels RJ. Molecular determinants of permeation through the cation channel TRPM6. Cell Calcium 2007;41:513-523.

3. Walder RY, Landau D, Meyer P, Shalev H, Tsolia M, Borochowitz Z, Boettger MB, Beck GE, Englehardt RK, Carmi R, Sheffield VC. Mutation of TRPM6 causes familial hypomagnesemia with secondary hypocalcemia. Nat Genet 2002;31:171-174. Epub 2002 May 28 
4. Voets T, Nilius B, Hoefs S, van der Kemp AW, Droogmans G, Bindels RJ, Hoenderop JG. TRPM6 forms the Mg2 + influx channel involved in intestinal and renal Mg2 + absorption. J Biol Chem 2004;279:19-25. Epub 2003 Oct 23

5. de Baaij JH, Hoenderop JG, Bindels RJ. Magnesium in man: implications for health and disease. Physiol Rev 2015;95:1-46.

6. Dai LJ, Ritchie G, Kerstan D, Kang HS, Cole DE, Quamme GA. Magnesium transport in the renal distal convoluted tubule. Physiol Rev $2001 ; 81: 51-84$

7. Sutton RA, Domrongkitchaiporn S. Abnormal renal magnesium handling. Miner Electrolyte Metab 1993;19:232-240.

8. Zhao Z, Pei Y, Huang X, Liu Y, Yang W, Sun J, Si N, Xing X, Li M, Wang O, Jiang Y, Zhang X, Xia W. Novel TRPM6 mutations in familial hypomagnesemia with secondary hypocalcemia. Am J Nephrol 2013; 37541-548. Epub 2013 May 16

9. Schlingmann KP, Sassen MC, Weber S, Pechmann U, Kusch K, Pelken L, Lotan D, Syrrou M, Prebble JJ, Cole DE, Metzger DL, Rahman S, Tajima T, Shu SG, Waldegger S, Seyberth HW, Konrad M. Novel TRPM6 mutations in 21 families with primary hypomagnesemia and secondary hypocalcemia. J Am Soc Nephrol 2005;16:3061-3069. Epub 2005 Aug 17

10. Katayama K, Povalko N, Yatsuga S, Nishioka J, Kakuma T, Matsuishi T, Koga Y. New TRPM6 mutation and management of hypomagnesaemia with secondary hypocalcaemia. Brain Dev 2015;37:292-298. Epub 2014 Jun 28

11. Jin-no Y, Kamiya Y, Okada M, Hirako M, Takada N, Kawaguchi M. Primary hypomagnesemia caused by isolated magnesium malabsorption: atypical case in adult. Intern Med 1999;38:261-265.

12. Hartnett KA, Stout AK, Rajdev S, Rosenberg PA, Reynolds IJ, Aizenman E. NMDA receptor-mediated neurotoxicity: a paradoxical requirement for extracellular $\mathrm{Mg} 2+$ in $\mathrm{Na}+/ \mathrm{Ca} 2+$-free solutions in rat cortical neurons in vitro. J Neurochem 1997;68:1836-1845.

13. Walder RY, Yang B, Stokes JB, Kirby PA, Cao X, Shi P, Searby CC, Husted RF, Sheffield VC. Mice defective in Trpm6 show embryonic mortality and neural tube defects. Hum Mol Genet 2009;18:4367-4375. Epub 2009 Aug 18

14. Lainez S, Schlingmann KP, van der Wijst J, Dworniczak B, van Zeeland F, Konrad M, Bindels RJ, Hoenderop JG. New TRPM6 missense mutations linked to hypomagnesemia with secondary hypocalcemia. Eur J Hum Genet 2014;22:497-504. Epub 2013 Aug 14

15. Guran T, Akcay T, Bereket A, Atay Z, Turan S, Haisch L, Konrad M, Schlingmann KP. Clinical and molecular characterization of Turkish patients with familial hypomag nesaemia: novel mutations in TRPM6 and CLDN16 genes. Nephrol Dial Transplant 2012;27:667-673. Epub 2011 Jun 9

16. Astor MC, Løvås K, Wolff AS, Nedrebø B, Bratland E, Steen-Johnsen J, Husebye ES. Hypomagnesemia and functional hypoparathyroidism due to novel mutations in the Mg channel TRPM6. Endocr Connect 2015;4:215-222. Epub 2015 Aug 13

17. Shalev H, Phillip M, Galil A, Carmi R, Landau D. Clinical presentation and outcome in primary familial hypomagnesaemia. Arch Dis Child 1998;78:127-130.

18. Dimke H, Hoenderop JG, Bindels RJ. Molecular basis of epithelial Ca2 + and Mg2 + transport: insights from the TRP channel family. J Physiol 2011;589:1535-1542. Epub 2010 Nov 1

19. Agus ZS. Hypomagnesemia. J Am Soc Nephrol 1999;10:1616-1622.

20. Altıncik A, Schlingmann KP, Tosun MS. A novel homozygous mutation in the transient receptor potential melastatin 6 gene: a case report. J Clin Res Pediatr Endocrinol 2016;8:101-104. Epub 2015 Dec 18

21. Apa H, Kayserili E, Agin H, Hizarcioglu M, Gulez P, Berdeli A. A case of hypomagnesemia with secondary hypocalcemia caused by Trpm6 gene mutation. Indian J Pediatr 2008;75:632-634. Epub 2008 Aug 31

22. Özlü SG, Kasapkara CS, Ceylaner S, Erat Nergiz M, Alan B, Yilmaz S, Citak Kurt AN. Mild hypotonia and recurrent seizures in an 8-monthold boy: Answers. Pediatr Nephrol 2010;34:1729-1731. Epub 2019 Mar 22 